\title{
Pembiayaan Perumahan Berasaskan Komoditi Murabahah: Kajian Kes di CIMB Islamic Bank
}

\author{
Home Financing Based on Commodity Murabahah: Case Study at CIMB Islamic Bank \\ Mohammad Taqiuddin Mohamad, ${ }^{*}$ Mohd Najdi Aminuddin, ${ }^{\mathrm{b}}$ Muhamad Husni Hasbulah ${ }^{\mathrm{c}}$ \\ a Department of Syariah and Economics Academy of Islamic Studies, Universiti Malaya (UM), \\ ${ }^{b}$ Bank Rakyat Malaysia Berhad, Kepala Batas, Pulau Pinang, \\ 'Fakulti Ekonomi dan Pengurusan, Universiti Kebangsaan Malaysia (UKM) \\ *Corresponding author: m.taqiuddin@um.edu.my
}

\section{Article history}

Received: 2017-12-08 Received in revised form: 2018-01-09 Accepted: 2018-01-12 Published online: 2018-10-31

\begin{abstract}
Commodity of Murabahah and Tawarruq are the concept that was applied in the products of home financing (Flexi Home Financing-i) at CIMB Islamic Bank. This product is one of products which is offered by CIMB Islamic Bank. Before of this, there are several concepts such as Bay' Bithamanil Ajil (BBA) and Bay' Inah have been applied in the products of home financing by Islamic Banks where it causes some controversies. The using of BBA and Inah as a contract in home financing's product have been criticized by some of the Islamic scholars especially from the Middle East Islamic scholars. Through the descriptive analysis, a case studies were conducted by collecting the data through an interviews. The study was found that a scheme of home financing through product called Flexi Home Financing-i offered by CIMB Islamic Bank is one form of innovative products in order to make the financing products offered to customers free from the elements of Riba. Additionally, it was alternative from using al-Inah which is controversies among the scholars. This study also found that this product is line up with the Shariah compliance and ability to stand up with the value of moral and ethics which is compliance with principles of Shariah.
\end{abstract}

Keywords: Commodity of Murabahah, Tawarruq, Home's Financing, Shariah

\begin{abstract}
Abstrak
Komoditi Muräbahah dan Tawarruq merupakan satu konsep yang diaplikasikan dalam produk pembiayaan perumahan Flexi Home Financing-i di CIMB Islamic Bank. Produk pembiayaan perumahan ini merupakan salah satu daripada produk perumahan yang ditawarkan oleh pihak CIMB Islamic Bank. Sebelum ini, beberapa konsep lain seperti Bay' Bithaman Ajil (BBA) dan Bay' Inah telah diaplikasikan dalam produk pembiayaan perumahan di perbankan Islam yang mana ianya menimbulkan kontroversi. Produk perumahan yang menggunakan konsep BBA dikatakan mengenakan caj bayaran balik yang tinggi, manakala penggunaan Bay' Inah pula dikritik hebat oleh sarjana Islam Timur Tengah kerana dikatakan salah satu helah daripada Riba. Melalui analisis deskriptif terhadap kajian kes yang diperolehi melalui temubual, kajian mendapati Skim pembiayaan perumahan melalui produk yang diberi nama Flexi Home Financing-i yang ditawarkan oleh CIMB Islamic Bank merupakan salah satu bentuk produk yang berinovasi dalam usaha menjadikan produk pembiayaan yang ditawarkan kepada pelanggan ini bebas dari unsur Riba secara khususnya selain menjadikannya alternatif kepada penggunaan al-I'nah yang dikatakan kontroversi dari aspek pematuhannya terhadap Syariah dan dikritik oleh kebanyakan sarjana Timur Tengah. Penilaian isu yang ditimbulkan berasaskan kepada kepatuhan Syariah di analisis, dan kajian mendapati produk pembiayaan perumahan yang ditawarkan ini mempunyai keselarasan dari sudut Syariah serta kebolehupayaannya untuk menepati kaedah-kaedah Fiqh dan prinsip Syarak yang berasaskan kepada nilai moral dan etika.
\end{abstract}

Keywords: Komoditi Murabahah, Tawarruq, Pembiayaan Perumahan, Syariah 


\subsection{PENDAHULUAN}

Jual beli merupakan salah satu kontrak Muamalah yang wujud dalam kegiatan ekonomi seharian. Islam telah menggariskan perkara-perkara yang dibenarkan dan dilarang dalam aktiviti perniagaan khususnya melibatkan aktiviti dalam pertukaran jual beli. Dalam urusan jual beli perkara utama yang perlu dipatuhi ialah berkaitan rukun dan syarat-syarat sepertimana yang telah dibicangkan di kalangan sarjana Islam. Diantara bentuk kesahan sesuatu kontrak jual beli ialah, ianya perlulah bebas dari sebarang bentuk unsur Riba sepertimana Firman Allah Taala dalam Surah al-Baqarah ayat 275: "Sesunggubnya Allah menghalalkan jual beli dan mengharamkan Riba". Pada zaman globalisasi ini telah muncul pelbagai penemuan dan produk baru dalam sistem perbankan dan kewangan Islam hasil usaha penyelidikan dan inovasi yang telah dijalankan. Sebagai contoh, penggunaan konsep Syariah seperti Tawarruq yang juga dikenali sebagai Komoditi Muräbahah telah diperkenalkan di Malaysia sebagai gantian kepada penggunaan Bay' al-Inah yang telah menimbulkan beberapa kontroversi kerana dikatakan hampir kepada Riba (Asyraf Wajdi, 2010).

Komoditi Murabahah merupakan salah satu bentuk transasksi jual beli komoditi yang menggunapakai kontrak Murabahah dan Tawarruq dalam operasinya sebagai alternatif kepada pembiayaan perumahan khususnya dalam menggantikan unsur al-Inah yang dikatakan telah menimbulkan kontroversi dan kritikan oleh sebahagian sarjana disebabkan ianya adalah helah kepada bentuk Riba. Oleh itu, kajian ini bertujuan menganalisis produk pembiayaan perumahan yang berasaskan kepada Komoditi Murabahah khususnya dari aspek kepatuhannya terhadap Syariah. Dengan menjalankan kajian kes, kajian ini memilih produk pembiayaan perumahan yang ditawarkan oleh CIMB Islamic Bank iaitu produk Flexi Home Financing-i sebagai salah satu bentuk instrument dalam kajian ini untuk menjalankan temubual dalam memperoleh data yang diperlukan. Pemilihan terhadap produk pembiayaan yang ditawarkan oleh CIMB Islamic Bank ini adalah disebabkan produk ini mengaplikasi dan menggunapakai konsep Komoditi Murabahah dalam menawarkan pembiayaan perumahannya kepada pelanggan di samping keunikan produk pembiayaan ini yang menghubungkan secara langsung pelanggan yang melanggan pembiayaan ini dengan Akaun Semasa Khas Mudharabah-i yang tidak terdapat dalam mana-mana pembiayaan perumahan di institusi perbankan Islam yang lain.

\subsection{METODOLOGI KAJIAN}

Artikel ini adalah satu kajian kes yang menjalankan satu penyelidikan dan penelitian terhadap fenomena yang berlaku dalam sistem perbankan Islam kini di mana pembiayaan berasaskan komoditi Murabahah menjadi pilihan bank-bank Islam sebagai ganti kepada pembiayaan berasaskan Bay' Bithamanil Ajil (BBA) yang telah diamalkan sebelum ini. Kajian ini memilih CIMB Islamic Bank sebagai sampel kajian kerana keunikan produk pembiayaan ini yang menghubungkan secara langsung pelanggan yang melanggan pembiayaan ini dengan Akaun Semasa Khas Mudharabah-i yang tidak terdapat dalam mana-mana pembiayaan perumahan di institusi perbankan Islam yang lain.

Kajian kes merupakan penyelidikan yang dilakukan terhadap sesuatu kesatuan sistem, sama ada yang berbentuk program ataupun kejadian yang terikat oleh tempat, waktu atau ikatan tertentu. Kajian kes dilaksanakan untuk menghimpun data, memperoleh makna dan memperoleh pemahaman daripada suatu kes. Proses kajian kes melibatkan pengumpulan data, mengenalpasti corak fenomena, mengakses fenomena, membina rekod, merekod maklumat, menyelesaikan isu lapangan dan menyimpan data (Creswell, 1994). 
Kajian kes juga menurut Stake (1995) dan Nisbet dan Watt (1994) adalah merujuk kepada pengertian memilih suatu (atau mungkin juga lebih dari satu) kejadian atau gejala sosial untuk dikaji dengan menerapkan pelbagai rangkai metode pengkajian. Pengertian ini sekaligus menjelaskan bahwa kajian kes adalah mengkaji aras mikro (meneliti satu atau beberapa kes), dan kajian kes adalah strategi pengkajian yang bersifat multi-metode. Mengenai hal terakhir ini, lazimnya pengkaji kes akan menggabungkan kaedah observasi, wawancara, dan analisis dokumen.

Oleh itu kajian kes yang dilakukan ini adalah bertujuan menyelidik produk pembiayaan perumahan yang berasaskan kepada Komoditi Murabahah khususnya dari aspek kepatuhannya terhadap Syariah. Dengan menjalankan kajian kes, kajian ini memilih produk pembiayaan perumahan yang ditawarkan oleh CIMB Islamic Bank iaitu produk Flexi Home Financing-i sebagai salah satu bentuk instrument dalam kajian ini untuk menjalankan temubual dalam memperoleh data yang diperlukan.

\subsection{KONSEP KOMODITI MURABAHAH}

Komoditi Murābahah umumnya merupakan satu kontrak jual beli yang berasaskan kepada prinsip Tawarruq jika ia melibatkan tiga pihak atau lebih. Komoditi Murabahah pula adalah perkataan gabungan diantara Komoditi dan Murabahah. Komoditi menurut kamus dewan merupakan barangan yang diperdagangkan terutamanya melibatkan keluaran ladang, bahan mentah dan bahan galian. Manakala Murabahah adalah sejenis transaksi yang sering diterjemahkan oleh institusi kewangan Islam sebagai harga kos ditambah harga jualan atau lebih dikenali dengan mark up price. Oleh itu dapat difahami bahawa komoditi Murabahah adalah satu bentuk urusniaga jual beli yang melibatkan pembelian barang-barang atau komoditi tertentu pada harga kos campur margin keuntungan (Murabahah) yang telah disetujui oleh kedua belah pihak (penjual dan pembeli) dan kemudiannya, komoditi tersebut akan dijual semula kepada peniaga komoditi yang lain (pihak ketiga) dengan tujuan untuk memperoleh wang tunai (Muhammad Hasbi \& Abdul Hakam, 2014).

Manakala Tawarruq yang menjadi elemen dalam komoditi Murabahah dari sudut bahasa adalah Masdar daripada Tawarraqa, YaTawarruqan (al-Zamakhsari, 1965; Ibrahim Anis et al, 1972; Ibn Manzur, 1990; Qal'ahji et al, 1996; Wizarat al-Awqaf wa al-Shu'un al-Islamiyyah, 2002) yang berasal daripada perkataan al-Wariq yang bermaksud wang atau dirham perak (Ibn Manzur, 1990). Manakala dari sudut istilah, Wahbah al-Zuhaily (2004) mendefinisikan Tawarruq dengan seseorang yang membeli sesuatu barang dengan pembayaran secara tangguh, kemudian orang itu menjual pula kepada orang lain dengan harga yang kurang daripada pembelian pertama bagi tujuan mendapatkan wang tunai. Manakala AAIOFI (2008) mendefinisikan Tawarruq pula sebagai membeli satu barang dengan harga bertangguh sama ada secara Musawamah atau Murabahah kemudian menjual secara tunai kepada pihak selain penjual asal bagi tujuan mendapatkan wang tunai.

Terdapat dua jenis Tawarruq. Pertama Tawarruq al-Fardi yang merujuk kepada keadaan pembeli pertama membeli barang secara ansuran dan menjualnya kepada pihak ketiga secara tunai dengan harga yang lebih rendah daripada harga asal untuk mendapatkan wang tunai. Dalam hal ini, pihak ketiga tidak boleh mempunyai perkaitan langsung dengan penjual pertama tadi (IBFIM, 2007). Manakala Tawarruq jenis yang kedua ialah Tawarruq al-Munazzam atau al-Masrafi yang merupakan pembelian barang terakhir tadi bertindak sebagai wakil kepada penjual barang yang pertama ataupun penjual pertama akan mewakili pembeli terakhir dalam menguruskan kontrak (Ab. Mumin Ab. Ghani \& Ahmad Sufyan Che Abdullah, 2006; Hassan, 2009). Jenis yang kedua ini selalu digunapakai oleh sistem perbankan moden untuk memenuhi kehendak pelanggan 
yang ingin mendapatkan wang tunai tanpa perlu mencari pembeli barang yang dibeli daripada bank.

\subsection{LATAR BELAKANG CIMB ISLAMIC BANK}

CIMB Islamic Bank adalah francais perkhidmatan perbankan dan kewangan Islam global bagi Kumpulan CIMB. Kumpulan CIMB adalah penyedia perkhidmatan kewangan yang kedua terbesar di Malaysia selepas Malayan Banking (Maybank). Kumpulan CIMB Bank yang diketuai oleh Ketua Pegawai Eksekutif, Datuk Seri Nazir Bin Razak melaksanakan sistem dwi perbankan iaitu menyediakan perkhidmatan kaunter konvensional dan kaunter Islam di setiap cawangannya bagi memberi perkhidmatan kepada pelanggan. Kumpulan CIMB disenaraikan di Bursa Malaysia melalui Bumiputra-Commerce Holdings Berhad (BCHB). Pada tahun 2004, CIMB telah bergabung dengan Bank Bumiputera-Commerce dan Southern Bank dan hasilnya telah terbentuk entiti yang digelar Commerce International Merchant Bankers (CIMB) (Laporan Tahunan CIMB, 2014).

Merujuk kepada CIMB Islamic, francais ini merupakan antara perbankan Islam Malaysia yang menawarkan penyelesaian kewangan yang inovatif, menyeluruh dan patuh Syariah untuk perbankan pelaburan, perbankan pengguna, pengurusan aset, perbankan swasta dan juga pengurusan kekayaan. CIMB Islamic beribu pejabat di Kuala Lumpur, Malaysia dan merupakan sebahagian daripada kumpulan perbankan kelima terbesar di ASEAN, dengan lebih daripada 40,000 kakitangan di 17 buah negara di seluruh ASEAN dan Asia dan 800 cawangan perniagaan meliputi Malaysia, Indonesia, dan juga Singapura. Pencapaian yang dikecapi ini membolehkan CIMB Islamic menyediakan pelbagai produk dan perkhidmatan kepada pelanggan komersial, korporat dan institusi di seluruh ASEAN, Timur Tengah, Asia Selatan, Asia Utara, dan pusatpusat kewangan antarabangsa yang utama. Produk dan operasi yang ditawarkan oleh CIMB diuruskan dengan pematuhan ketat dengan prinsip-prinsip Syariah di bawah bimbingan Jawatankuasa Syariah CIMB Islamic, yang terdiri daripada ulama Islam yang terkemuka di dunia (CIMB, 2015).

\subsection{KAJIAN KES: PRODUK PEMBIAYAAN PERUMAHAN DI CIMB ISLAMIC BANK}

Jadual di bawah menunjukkan skim pembiayaan hartanah yang ditawarkan oleh perbankan CIMB Islamic Bank Berhad. Dalam kajian ini, pengkaji hanya menumpukan kepada skim pembiayaan Flexi Home Financing-i yang berdasarkan konsep Komoditi Muräbahah (Tawarruq).

\section{Produk Pembiayaan Hartanah Terkenal CIMB Islamic}

\begin{tabular}{|c|c|c|c|c|}
\hline \multicolumn{5}{|c|}{ Produk Pembiayaan Hartanah Terkenal CIMB Islamic Bank } \\
\hline Commodity & Ijarah Property & Variable Home & Flexi Home & Term Financing-i \\
Murababah Flexi & Financing-I \& & Financing-i 2 & Financing- $i$ & (Residential Vacal \\
Home Financing-i $i$ & Bussiness Premises & Bussiness Premises & Flexi Home & Land) \\
& & & Bussiness-i & \\
\hline
\end{tabular}

\subsection{FLEXI HOME FINANCING-i}

Pembiayaan perumahan Flexi Home Financing-i adalah salah satu produk perumahan yang ditawarkan oleh CIMB Islamic Bank. Skim ini dikategorikan sebagai skim pembiayaan hartanah 
yang ditawarkan untuk kemudahan pembeli rumah. Ia merupakan produk pembiayaan perumahan yang inovatif serta memberikan fleksibiliti dan kemudahan kepada pelanggan.

Produk Flexi Home Financing-i adalah berteraskan konsep Tawarruq. Konsep Tawarruq mempunyai persamaan dengan Komoditi Muräbahah. Pembeli yang menggunakan produk pembiayaan Flexi Home Financing-i akan mendapatkan keistimewaan yang tidak terdapat pada produk pembiayaan lain iaitu dihubungkan terus dengan Akaun Semasa Khas Mudharabah- $I^{1}$. Secara asasnya, pembiayaan flexi ialah pembiayaan yang mana pelanggan dapat mengambil dan memasukkan wang ke dalam akaun pinjaman tanpa perlu menanggung sebarang yuran ataupun prosedur. Setiap bulan, jumlah ansuran akan ditolak daripada akaun semasa pelanggan seperti dijadualkan.

Apabila pelanggan menggunakan produk Flexi Home Financing-i secara automatiknya akan dihubungkan terus kepada Akaun Semasa Khas Mudharabah-I. Pelanggan yang menyimpan di dalam akaun ini akan menikmati caj keuntungan yang lebih rendah bagi pembiayaan perumahan dan pada masa yang sama akan memperoleh keuntungan bulanan (Farah Nadia, 2014). Kelebihan penggunaan akaun ini ialah akan mengimbangi amaun pembiayaan perumahan pelanggan dan menyebabkan caj keuntungan dapat diturunkan dan sekaligus akan mengurangkan tempoh pembayaran pelanggan.

\section{Jadual 1: Baki Prinsipal: RM 200,000}

\begin{tabular}{|c|c|}
\hline Tarikh & Baki di dalam Akaun Semasa Khas Mudharabah-i \\
\hline 30 Sept & RM 50,000 \\
\hline 1 Okt & RM 80,000 \\
\hline
\end{tabular}

Sumber : Lembaran Produk Flexi Home Financing-i CIMB Islamic (2012)

\section{Jadual 2: Pengiraan Berdasarkan Caj Keuntungan Harian.}

\begin{tabular}{|c|c|}
\hline Tarikh & Caj Keuntungan Harian \\
\hline $1 \mathrm{Okt}$ & RM 200,000-RM 50,000 x 4.75\% X 1/365 = RM 19.52 \\
\hline $2 \mathrm{Okt}$ & RM 200,000- RM 80,000x 4.75\% x 1/365= RM 15.62 \\
\hline
\end{tabular}

Sumber: Lembaran Produk Flexi Home Financing-i CIMB Islamic 2012

\subsection{CIRI-CIRI FLEXI HOME FINANCING-i}

Fleksibiliti: Pelanggan boleh megeluarkan wang daripada Akaun Semasa Khas Mudharabah-I melalui cek atau ATM pada bila-bila masa dan pelanggan akan menikmati kadar keuntungan yang fleksibel berlandaskan pergerakan Kadar Pembiayaan Asas (KPA) ${ }^{2}$.

Perolehan keuntungan ke atas Akaun Semasa Khas Mudharabah-I: Pelanggan akan menikmati keuntungan ke atas baki harian yang terdapat di dalam Akaun Semasa Khas Mudharabah-i.

Bayaran Mudah: Pelanggan boleh membayar ansuran bulanan melalui mana-mana cawangan atau melalui mesin deposit tunai di cawangan CIMB Bank seluruh negara. Penjimatan Duti Setem: 20\% diskaun bagi permohonan pembiayaan yang baru dan pengecualian penuh duti setem bagi permohonan pembiayaan semula daripada kemudahan konvensional kepada

\footnotetext{
1 Akaun Semasa Mudharabah-I: CIMB Islamic Bank Berhad ("Bank”) akan menerima jumlah wang yang dideposit dan sebarang jumlah wang yang akan dideposit selepas itu dalam Akaun Semasa-i berdasarkan prinsip Shariah iaitu Wadiah dan/atau Mudharabah.

${ }^{2}$ kadar caj keuntungan tidak akan melebihi kadar keuntungan berdasarkan kontrak. 
pembiayaan berlandaskan Syariah (untuk jumlah baki prinsipal sahaja). Jumlah dan Tempoh Pembiayaan: Jumlah pembiayaan minimum adalah RM 150,000 dan tempoh minimum: 5 tahun, tempoh maksimum 35 tahun atau sehingga pemohon mencapai umur 70 tahun.

\subsection{SYARAT-SYARAT PEMBIAYAAN FLEXI HOME FINANCING-i}

Antara syarat-syarat utama untuk memohon skim pembiayaan ini ialah :

Individu yang berusia 18 tahun dan ke atas serta warganegara Malaysia layak untuk memohon pembiayaan ini. Antara dokumen yang dikehendaki semasa pembiayaan ialah :

1. Borang Permohonan

2. Kad Pengenalan

3. Slip gaji (3 bulan berturut-turut)

4. EPF Statement (2 tahun terakhir)

5. Borang perjanjian jual beli (Sales \& Purchase agreement)

Keperluan majikan :

1. Kad pengenalan

2. Slip gaji pekerja (3 bulan berturut-turut)

3. Surat pengesahan pekerjaan dan imbuhan

4. EPF Statement (3 bulan berturut-turut)

5. Borang perjanjian jual beli (Sales \& Purchase agreement).

\subsection{LANGKAH-LANGKAH MENDAPATKAN PEMBIAYAAN FLEXI HOME FINANCING-i}

Berdasarkan temubual yang dijalankan, berikut merupakan langkah-langkah untuk mendapatkan pembiayaan perumahan di CIMB Islamic Bank. Seperti yang dimaklumkan produk pembiayaan perumahan ini berdasarkan konsep Komoditi Muräbahah.

\section{Rajah 1: Proses Pembiayaan Perumahan}

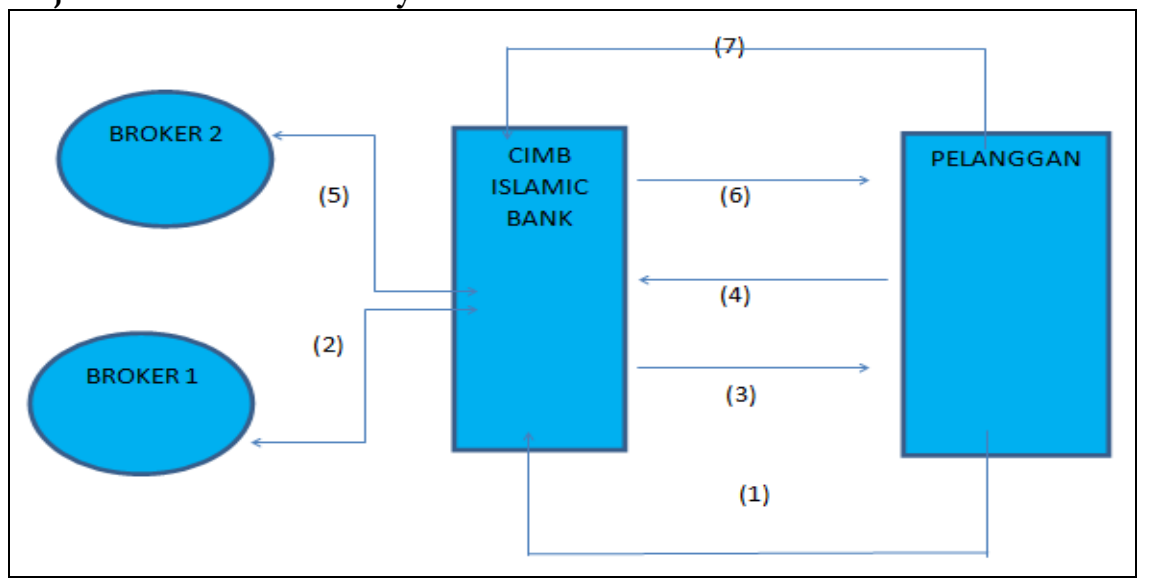

Sumber : Lakaran Melalui Temubual Bersama Pegawai CIMB Islamic (Zuhairi, 2014)

1. Pelanggan yang memilih skim Flexi Home Financing-i untuk membeli rumah perlu datang ke CIMB Islamic Bank untuk membuat permohonan. Bank akan mendapatkan dokumen transaksi daripada pelanggan. Konsep yang digunakan dalam pembiayaan perumahan ini ialah Komoditi Muräbahab ( Tawarruq).

2. Pihak Bank akan membeli komoditi yang berkaitan melalui Broker 1. 
3. Melalui kontrak Muräbahah, bank akan menjual komoditi itu kepada pelanggan pada harga yang ditetapkan bank (pokok+keuntungan) berdasarkan pembayaran tertangguh.

4. Menerusi kontrak Wakalah pelanggan akan meminta bank untuk menjual semula komoditi tersebut di pasaran.

5. Bank akan bertindak sebagai ejen jualan yang dilantik oleh pelanggan dan akan menjual komoditi tersebut kepada Broker 2.

6. Bank kemudian akan mengkreditkan hasil daripada jualan komoditi ke dalam akaun pelanggan.

7. Pelanggan perlu membayar ansuran yang ditetapkan kepada bank (pokok +keuntungan) melalui kaedah yang dipersetujui.

Dalam skim pembiayaan Flexi Home Financing-i jika pelanggan gagal membuat pembayaran dalam tempoh yang ditetapkan maka kadar pampasan (Ta'widh) yang dikenakan ialah sebanyak (1\%) atau sebarang kadar lain yang diluluskan oleh Bank Negara Malaysia (BNM) ke atas baki prinsipal yang gagal dijelaskan (Lembaran Pendedahan Produk).

Jika pembayaran masih gagal dijelaskan selepas tempoh, maka kadar Ta'widh yang dikenakan tidak akan melebihi Kadar Pasaran Wang Antara Bank Islam (IIMM) semalaman harian yang ditetapkan oleh bank negara atau sebarang kadar lain yang diluluskan oleh bank negara ke atas baki prinsipal yang belum dijelaskan. Antara syarat Ta'widh yang ditetapkan ialah jumlah Ta'widh terkumpul tidak boleh melebihi $(100 \%)$ daripada baki prinsipal yang belum dijelaskan (Lembaran Pendedahan Produk).

Seterusnya, jika pelanggan dapat menjelaskan bayaran ansuran sepenuhnya sebelum tarikh matang pelanggan mungkin dikenakan caj penyelesaian awal atau ibra' (rebat). Seharusnya pelanggan perlu bertanggungjawab sepenuhnya jika gagal membayar ansuran bulanan yang ditetapkan. Pihak bank boleh menarik balik rumah itu jika pelanggan gagal menjelaskan dalam tempoh yang ditetapkan kerana rumah itu masih dalam pegangan bank, dan hanya $100 \%$ menjadi milik pembeli apabila pembeli menjelaskan sepenuhnya pembiayaan yang dipersetujui di awal kontrak (Farah Nadia, 2014).

\subsection{ANALISIS PELAKSANAAN KOMODITI MURABAHAH DALAM PRODUK PEMBIAYAAN FLEXI HOME FINANCING-i DI CIMB ISLAMIC}

Komoditi Muräbahah yang berdasarkan konsep Tawarruq telah digunakan dalam Flexi-Home Financing-i di CIMB Islamic. Terdapat beberapa isu yang berkaitan diketengahkan dalam kajian untuk perbincangan sama ada isu tersebut memberi kesan terhadap kesahan produk pembiayaan ini. Oleh itu, diantara isu yang timbul berkaitan pelaksanaan komoditi Murabahah dalam produk ini adalah seperti berikut:-

Penggunaan kontrak Tawarruq dalam operasi komoditi Murabahah: Tawarruq di sini merujuk kepada penglibatan pelbagai pihak dalam transaksi jual beli iaitu di mana dalam kes produk pembiayaan perumahan Flexi Home Financing-i ini melibatkan empat pihak iaitu pihak bank (CIMB Islamic), pelanggan, broker 1 dan broker 2. Dalam hal ini, Tawarruq yang di gunapakai oleh CIMB Islamic bukannya Tawarruq yang berbentuk Muntabiq. Iaitu tidak wujud perkaitan diantara Broker 1 dengan Broker 2 dan kedua-dua broker ini di bawah pengurusan yang berbeza (Muhammad Hasbi \& Abdul Hakam, 2014). Oleh itu, jelaslah transaksi Tawarruq yang wujud dalam produk pembiayaan perumahan Flexi Home Financing-i ini adalah transaksi jual beli yang hakiki dan bukannya direka-reka walaupun dalam keadaan ini terdapatnya unsur pengaturan pada persepakatan awal. Maka tidak timbul isu Syariah dalam hal ini. Ini selaras dengan pandangan ulama' kontemporari yang mengharuskan penggunaan Tawarruq dalam 
perbankan Islam ialah Majlis Penasihat Kewangan Islam Timur Tengah seperti Arab National Bank, HSBC Amanah, Shamil Bank, dan The National Commercial Bank yang telah mengharuskan Tawarruq Munāzam. Antara ahli penasihat yang telah meluluskan Tawarruq dalam perbankan Islam ialah 'Abd Allah bin Sulayman al-Mani' selain daripada cendekiawan Islam lain seperti Sulayman Nasir al-'Ulwan (Asmak et al, 2010).

Penggunaan komoditi Murabahah di perbankan Islam: Isu penggunaan komoditi Murabahah dalam perbankan Islam menunjukkan keselarasan prinsip yang digariskan oleh para Fuqaba' iaitu berdasarkan hujah mekanisme penggunaan komoditi Muräbahah yang merupakan pengembangan daripada Bay' al-Muräbahah yang telah diharuskan penggunaannya (Ubay Harun, 2006). Majlis Penasihat Syariah Bank Negara Malaysia telah sepakat membenarkan pengggunaan komoditi Muräbahah pada 28 Julai 2005. Tujuannya, adalah untuk menawarkan instrumen baru kepada institusi kewangan Islam untuk menguruskan kecairan dana di Islamic Inter-bank Money Market (IIMM). Komoditi Muräbahah juga memberikan pulangan berdasarkan pada margin atau mark-up daripada penjualan atau pembelian aset (Asyraf Wajdi, 2007). Oleh itu tidak timbul isu dalam penggunaan komoditi Murabahah seperti yang diamalkan dalam industri perbankan Islam kini kerana selain ianya adalah instrumen baru, komoditi Murababah juga adalah satu bentuk tolong menolong (Ta'awun) dalam kalangan institusi kewangan Islam khususnya dalam pasaran wang antara bank-bank Islam.

Penggunaan kontrak Murabahah dalam produk pembiayaan Flexi Home Financingi. Dalam hal ini pihak CIMB Islamic bertindak membeli komoditi dari Broker 1 pada harga kos dan menjualnya kepada pelanggan dengan harga kos ditambah dengan margin. Oleh itu, isu berkaitan kontrak Murabahah tidak wujud kerana sepertimana yang telah dipersetujui oleh pihak bank dengan pelanggan tidak timbul isu yang meragukan dari aspek Syariah terhadap penggunaan kontrak Murabahah dalam produk pembiayaan perumahan ini yang mampu menjejaskan kesahan dalam transaksi ini. Ini kerana jelas menunjukkan bahawa bank telah membeli komoditi pada harga kos dan menjualkannya kepada pelanggan dengan harga margin sepertimana yang telah dipersetujui.

Kontrak Hibrid: Amalan dalam penggunaan kontrak Hibrid menjelaskan wujudnya gabungan beberapa kontrak dalam satu transaksi. Dalam konteks Fiqh Muamalat dikenali sebagai al-'Uqudal Murakkabah dan al-Jam'u Bayna al-Uqud. Nazih Hammad (2005) mendefinisikan kontrak hibrid sebagai kesepakatan dua pihak untuk melaksanakan suatu akad yang mengandungi dua akad atau lebih seperti akad jual beli dengan akad sewa, hibah, wakalah, qard, muzara'ah, sarf, syirkah, mudharabah dan sebagainya, sehingga semua akibat hukum akad-akad yang terhimpun tersebut, serta semua hak dan kewajipan yang ditimbulkannya dianggap sebagai satu kesatuan yang tidak dapat dipisahkan sebagaimana akibat hukum dari satu akad. Dalam hal gabungan kontrak yang dapat dikenalpasti dalam produk pembiayaan ini adalah gabungan diantara kontrak Murabahah, Tawarruq dan Wakalah dan penggunaannya adalah dibenarkan sepertimana keputusan Resolusi No. 25 dalam Majlis Penasihat Syariah AAOIFI yang telah menetapkan penggabungan lebih daripada satu kontrak adalah dibenarkan dengan syarat kontrak itu sendiri dibenarkan Syarak dan setiap kontrak mestilah berdiri sendiri secara berasingan iaitu tanpa mengikat antara satu sama lain. Oleh itu, gabungan diantara kontrak amat diperlukan untuk memenuhi keperluan pelanggan dan institusi kewangan Islam di samping dapat meningkatkan kepelbagaian dalam rangkaian produk kewangan Islam.

Ta'widh dan Ibra' dalam Flexi Home Financing-í. Ta'widh secara umumnya didefinisikan sebagai memberi pampasan atau imbalan atas kerugian yang dialami akibat kemudaratan yang ditimbulkan. Manakala Majma' Fiqh Islämi pula mendefinisikan Ta'widh sebagai 
membayar imbalan atau pampasan kewangan akibat menyebabkan kemudaratan dan kesusahan kepada pihak lain (BNM, 2005). Berdasarkan definisi institusi perbankan Islam, Ta'widh adalah denda yang dikenakan ke atas pelanggan yang lewat atau sengaja menangguhkan baki prinsipal yang dikenakan oleh pihak bank atas sebab perjanjian jual beli atau sebarang bentuk pembiayaan yang telah dimeterai. Dalam konteks Ta'widh yang dikenakan terhadap pelanggan yang lewat menjelaskan baki prinsipal tertunggak dalam tempoh yang ditetapkan, kadar pampasan yang dikenakan adalah (1\%) setahun atau kadar lain yang ditetapkan oleh Bank Negara Malaysia (BNM) ke atas pembayaran lampau dari tempoh tarikh bulanan yang ditetapkan oleh pihak CIMB Islamic Bank. Jika kegagalan membayar baki prinsipal selepas tempoh, maka Ta'widh yang akan dikenakan tidak akan melebihi Kadar Pasaran Wang Antara Bank Islam (IIMM) yang diluluskan oleh bank negara ke atas baki prinsipal yang tertunggak. Kadar Ta'widh yang dikenakan oleh pihak bank akan dikumpulkan bersama Gharamah dan akan disalurkan kepada mana-mana pertubuhan amal yang diluluskan oleh Majlis Penasihat Syariah CIMB Islamic Bank. Ta'widh perlu dilaksanakan dalam perbankan Islam ke atas pelanggan yang lewat atau sengaja menangguhkan baki prinsipal yang ditetapkan. Jika Ta'widh tidak boleh dilaksanakan maka pelanggan bebas atau boleh menangguhkan bayaran prinsipal sesuka hati. Hal ini memberi risiko ke atas perjalanan operasi CIMB Islamic Bank yang perlu modal daripada pelanggan untuk dilaburkan dan pengembangan operasi. Pihak bank akan rugi dan akan menutup operasi jika keadaan ini berlaku. Ta'widh dapat memberi pengajaran kepada pelanggan yang perlu menanggung obligasi atas setiap tindakan mereka dan menghalang perbuatan sengaja pelanggan yang melambat-lambatkan sebarang bayaran. Walaupun begitu, pihak bank perlulah menggunakan budi bicara dan berbincang terlebih dahulu dengan pelanggan sebelum sebarang tindakan dikenakan. Manakala Ibra' pula bermaksud menggugurkan hak tuntutan atas sesuatu perkara, hak yang dimaksudkan ialah tanggungan pihak lain yang perlu dilaksanakan terhadapnya. Dalam istilah perbankan Islam, Ibra' adalah diskaun atau rebat yang diberi kepada pelanggan yang dapat menyelesaikan bayaran dengan lebih awal sebelum tempoh yang ditetapkan. Manakala di perbankan konvensional, pelanggan hanya perlu membayar baki amaun prinsipal dan faedah yang diperoleh (earned interest) pada masa penyelesaian awal dibuat. Pihak CIMB Islamic Bank telah menetapkan syarat terhadap penyelesaian awal sebahagian daripada harga jualan bank dan jumlah yang perlu dibayar balik adalah 1. Mestilah berada dalam gandaan tidak kurang daripada (6) kali jumlah ansuran. 2. Akan digunapakai mengikut aturan kematangan secara sonsang (inverse order of maturity); dan 3. Tidak akan menjejaskan kewajipan pemohon untuk membayar ansuran berikutnya tepat pada masanya dan sebarang jumlah yang dibayar tidak boleh dikeluarkan semula selepas itu. Pemberian Ibra' kepada pelanggan yang menyelesaikan pembayaran awal sebelum tempoh matang pembiayaan merupakan suatu kemaslahatan umum dan tanggungjawab sosial pihak bank. Dalam konteks pemberian Ibra' merupakan tanggungjawab pihak bank untuk melaksanakan janji tersebut kepada pelanggan.

Kewujudan unsur Gharar atau risiko: Gharär bermaksud ketidakpastian terhadap sesuatu perkara yang wujud. Apa yang dimaksudkan dengan gharär dalam pembiayaan perumahan adalah berkaitan dengan ketidakpastian terhadap rumah yang dibeli oleh pelanggan dapat disiapkan atau tidak dalam tempoh yang ditetapkan. Masalah projek perumahan terbengkalai merupakan suatu masalah yang sering terjadi apabila pemaju perumahan gagal menyiapkan rumah yang dibeli oleh pelanggan. Kesan yang dihadapi daripada projek perumahan terbengkalai akan ditanggung sepenuhnya oleh pelanggan dan bukannya pihak bank. Realiti daripada kes yang berlaku ini, apabila rumah gagal disiapkan atau terbengkalai, sudah pasti pelanggan akan menyalahkan pihak bank kerana mereka perlu membayar bayaran ansuran bulanan kepada pihak bank walaupun berlaku masalah ini. Pelanggan berpendapat dalam kes begini, pihak bank perlu bertanggungjawab ke atas masalah yang terjadi. Sepatutnya, jika berlaku kes sebegini, pelanggan 
perlu mengetahui perjanjian asal jual beli (sales and purchases agreement) antara pihak bank dan pelanggan di mana dalam perjanjian asal jika berlakunya masalah rumah dibeli oleh pelanggan gagal disiapkan, maka pihak bank tidak akan bertanggungjawab sepenuhnya (CIMB Islamic Bank, 2012). Pelanggan perlu mengetahui rumah yang dibeli itu adalah milik sepenuhnya oleh pihak bank dan akan menjadi milik sempurna pelanggan apabila tamat tempoh bayaran ansuran bulanan yang telah dipersetujui antara kedua-dua pihak. Kegagalan pihak pemaju menyiapkan rumah akan menjadi risiko besar yang perlu dihadapi oleh pelanggan. Pelanggan juga wajib melangsaikan bayaran ansuran bulanan kepada pihak bank sehingga tamat tempoh bayaran walaupun rumah yang dibeli gagal disiapkan (Farah Nadia, 2014). Hal ini disebabkan baki prinsipal yang dikenakan terhadap pelanggan terus berjalan. Pihak bank tidak boleh memberi jaminan yang rumah dibeli oleh pelanggan akan siap, kerana tugas utama pihak bank hanya sebagai pihak pembiaya yang memberi modal kepada pelanggan. Perkara ini yang mewujudkan unsur gharar dalam skim perumahan yang ditawarkan dan memberi risiko kepada pelanggan.

Kesimpulannya, isu pelaksanaan komoditi Murabahah dalam pembiayaan perumahan Flexi Home Financing-i di CIMB Islamic Bank adalah selaras dengan kepatuhannya terhadap Syariah. Ini kerana segala unsur dan elemen yang dibincangkan di atas mempunyai sandaran dan hujah daripada sarjana Islam dalam menjustifikasikan kedudukan produk ini dalam menepati dan menghindari kehendak dan kepatuhan kepada Syariah itu sendiri di samping kehujahan sarjana berasaskan kepada dalil yang disepakati iaitu al-Quran dan al-Sunnah. Maka produk seperti pembiayaan perumahan yang berasaskan kepada komoditi Murababab ini perlu dipelbagaikan lagi dari aspek penggunaan dalam instrumen kewangan Islam yang lain kerana ianya menjadi alternatif yang baik dalam menghindari isu-isu utama Syariah seperti Riba, Gharar dan lain-lain.

\subsection{ANALISIS KAEDAH FIQH DAN PRINSIP SYARAK DALAM PRODUK PEMBIAYAAN PERUMAHAN FLEXI HOME FINANCING-i}

Kewujudan kaedah Fiqh dan prinsip Syarak dalam produk pembiayaan perumahan Flexi Home Financing-i yang ditawarkan oleh CIMB Islamic Bank dapat dikenalpasti melalui modus operasi yang di amalkan oleh CIMB Islamic terhadap produk pembiayaan perumahan yang ditawarkannya. Berikut adalah beberapa kaedah Fiqh yang telah dikenal pasti wujud dalam produk pembiayaan ini.

Asal 'Aqad dan syarat adalah harus kecuali jika terdapat dalil yang mengharamkannya (al-Suyuti, $\mathbf{9 1 1 H}$ ): Pelanggan yang memilih produk Flexi Home Financing-i untuk membeli rumah perlu datang ke CIMB Islamic untuk membuat permohonan. Bank akan mendapatkan dokumen yang diperlukan daripada pelanggan. Konsep yang digunakan dalam pembiayaan perumahan ini ialah komoditi Muräbahah (Tawarruq). Pada langkah pertama ini, telah wujud akad yang melibatkan Ijab dan Qabul antara pelanggan dan pihak bank. Akad inilah yang mengikat kesepakatan antara pelanggan dan pihak bank. Oleh itu, pentingnya peranan akad yang menyebabkan proses perjanjian (W'ad) antara pelanggan dan pihak bank dimeterai.

Asal sesuatu muamalah itu harus, kecuali jika terdapat dalil yang mengharamkannya: Melalui kontrak Muräbahah, bank akan menjual komoditi itu kepada pelanggan pada harga yang ditetapkan bank (pokok+keuntungan) berdasarkan pembayaran tertangguh. Dalam langkah ketiga ini berlakunya Bay' al-Muräbahah merupakan 'Aqad jual beli yang diharuskan di dalam Islam. Ia merupakan satu bentuk jual beli yang mengambil tambahan untung daripada harga pokok dan dibenarkan Syara'. Bay' al-Muräbahah bertepatan dengan kaedah Figh ini.

Page 77 
Prinsip kerjasama dan tolong menolong: Pihak Bank akan membeli komoditi tertentu melalui Broker 1. Pada langkah kedua, proses ini berlakunya konsep Wakalah apabila pihak pelanggan mewakilkan kepada pihak bank untuk membeli komoditi daripada Broker 1. Konsep Wakalah adalah diharuskan dalam Syarak. Pada langkah kedua juga terlaksananya prinsip Ta'awnn iaitu kerjasama dan tolong menolong antara kedua-dua pihak. Prinsip Ta'awun menepati perintah Allah dalam al-Quran berdasarkan dalil dalam Surah al-Maidah ayat 2 "Dan hendaklah kamu bertolong-tolongan untuk membuat kebajikan dan bertakwa dan janganlah kamu bertolong-tolongan pada melakukan dosa (maksiat) dan penceroboban dan bertakwalah kepada Allab SWT, kerana sesunggubnya Allah Maha Berat azab seksaNya (bagi sesiapa yang melanggar perintabNya)".

Prinsip amanah dan jujur dalam setiap tindakan (responsibility): Pembeli rumah yang memilih produk pembiayaan ini perlu mematuhi prosedur pembiayaan yang ditetapkan oleh pihak bank terlebih dahulu. Antaranya, pembeli perlu mengisi borang permohonan pembiayaan, membawa kad pengenalan, gambar passport, salinan slip gaji ( 3 bulan berturut-turut), penyata EPF ( 2 tahun terkini) dan borang perjanjian jual beli (sales \& purchase agreement). Kegagalan untuk menyediakan item-item yang diminta akan menyebabkan proses permohonan tergendala. Pembeli juga tidak boleh menulis maklumat atau dokumen palsu, jika terdapat butiran palsu bank akan membatalkan perjanjian (Farah Nadia, 2014).

Hasil kajian menunjukkan produk pembiayaan perumahan yang diamalkan oleh CIMB Islamic Bank adalah selaras dan menepati kaedah Figh dan prinsip Syarak seperti yang dinyatakan. Kebolehan produk ini menepati kaedah Figh dan prinsip Syarak menggambarkan bahawa produk yang wujud dalam kewangan Islam secara khususnya perlulah bersifat dinamik dan unik dalam menjelaskan kedudukannya dalam memenuhi aspek etika dan nilai moral. Kebolehcapaian terhadap etika dan nilai moral akan menjadikan sesuatu produk kewangan itu menepati kehendak dan matlamat Syarak di samping menjadikan perekonomian secara Islam yang wujud dalam kewangan Islam itu sendiri bersifat unik dan istimewa.

\subsection{PENUTUP}

Skim pembiayaan perumahan melalui produk yang diberi nama Flexi Home Financing- $i$ yang ditawarkan oleh CIMB Islamic Bank merupakan salah satu bentuk produk yang berinovasi dalam usaha menjadikan produk pembiayaan yang ditawarkan kepada pelanggan ini bebas dari unsur Riba secara khususnya selain menjadikannya alternatif kepada penggunaan al-I'nab yang dikatakan kontroversi dari aspek pematuhannya terhadap Syariah dan dikritik oleh kebanyakan sarjana Timur Tengah. Penilaian isu yang ditimbulkan berasaskan kepada kepatuhan Syariah di analisis, dan kajian mendapati produk pembiayaan perumahan yang ditawarkan ini mempunyai keselarasan dari sudut Syariah serta kebolehupayaannya untuk menepati kaedah-kaedah Fiqh dan prinsip Syarak yang berasaskan kepada nilai moral dan etika. Oleh itu, pembangunan dalam produk kewangan Islam secara khususnya perlu dipertingkatkan lagi agar ianya menjadi suatu sumbangan yang seiring dengan pembangunan Ekonomi Islam sepertimana pembangunan produk pembiayaan yang berasaskan komoditi Murabahah ini mampu untuk menjadi platform kepada penyediaan lebih banyak lagi instrumen kewangan Islam yang lain.

\section{Rujukan}

AAOIFI. (2008). Al-Ma'ayir al-Shar'iyyah. Resolusi No 30 (Tawarruq Item) 4/1. Bahrain:AAOIFI. Hlm 493

AAOIFI. (2007; 2008). Shariah Standards for Islamic Financial Institutions. Shariah Standard No. (25): Combination of Contracts. (Bahrain: AAOIFI)

Page 78 
Ab. Mumin Ab. Ghani \& Ahmad Sufyan Che Abdullah. (2006). Tawarruq: Konsep dan Aplikasi dalam Kewangan Islam. Dlm. Ab. Ghani \& Fadillah Mansor (pnyt.). Dinamisme Kewangan Islam di Malaysia. Kuala Lumpur: Penerbit Universiti Malaya. hlm.117-131

Al-Suyuti. (911H). al-Asbah wa al-Naz̧a’ir. Beirut: Dār al-Fikr. h.309

Al-Zamakhsari, Abi Qasim Mahmud Ibn 'Umar. (1385H/1965). Asas al-Balaghah. Beirut: Dar Sadir. Hlm 672

Asmak Abd Rahman, Shamsiah Mohammad dan Iman Mohd Salleh. (2010). "Bay' al-Tawarruq dan Aplikasinya Dalam Pembiayaan Peribadi di Bank Islam Malaysia Berhad.” Jurnal Syariah. Jil 18. Bil 2. hh. 333-360

Asyraf Wajdi Dusuki. (2010). Can Bursa Malaysia's Suq al-Sila' (Commodity Murababah House) Resolve the Controversy over Tawarruq, Kertas Kajian ISRA 10.

Asyraf Wajdi Dusuki. (2007). "Commodity Murābahah Programme (CMP): An Innovative Approach to Liquidity Management”. Journal of Islamic Economics, Banking and Finance. Vol 3. No 1. 1-23

Asyraf Wajdi Dusuki. (2010). Konsep dan Operasi SWAP Sebagai Mekanisme Lindungan Nilai dalam Institusi Kewangan Islam. Dlm. Muhammad Ali Jinnah Ahmad (ed.). Muzakarah Cendekiawan Syariah Nusantara ke-3, 2009-Operasi dan Perbendaharaan Kewangan Islam, 25-26 Mei, Jakarta, Indonesia, hlm.32-74, Kuala Lumpur: International Syariah Research Academy for Islamic Finanace (ISRA).

Bank Negara Malaysia BNM. (2005). Resolusi Majlis Penasihat Syariah Bank Negara. Kuala Lumpur. hlm. 91

CIMB Islamic. (2012. Lembaran Produk Flexi Home Financing-i

CIMB Islamic. (2015). diakses dari http://www.cimbislamic.com/en/who-we-are.html, pada 14hb Januari 2015

CIMB Islamic Bank. (2012). Lembaran Pendedahan Produk

CIMB Islamic Bank. (2014). Produk Pembiayaan Hartanah CIMB Islamic diakses dari http://cb.cimbislamic.com/index.php?ch=ci_per_hf\&pg=ci_per_hf_buy\&tpt=cimb_islamic pada 9 Disember 2014

CIMB Islamic Bank Berhad. Lembaran Pendedahan Produk

Creswell, J.W. (1994). Research Design: Qualitative \& Quantitative Approaches. Thousand Oaks: Sage Publications.

Farah Nadia Zahari. (2014). ( Personal Financial Consultant CIMB Bank Berhad) dalam temubual dengan pengkaji 4 Disember 2014, 3.00 ptg.

Hassan, Hussin Hamid. (2009). al-Tawarruq al-Masrafi al-Munazzam, Munazzamah al-Mu'tamar al-Islami, Majma' al-Fiqh al-Islami al-Duwali, 26-30 April 2009. hlm.1. dipetik daripada Asyraf Wajdi Dusuki (2010).

IBFIM. 2007. Soal-Jawab Kewangan Islam. Sumber: Utusan Malaysia OnLine, Isnin, 5 November 2007, dari http://www.ibfim.com, diakses pada 23 Januari 2010.

Ibn Manzur, Muhammad Ibn Mukarram. (1990). Lisan al-'Arab. Beirut: Dar al-Fikr. Jil 10. Hlm 374-375

Ibrahim Anis et al. (1972). Al-Mu'jam al-Wasit. Al-Qahirah: t.pt. Jil 1. Hlm 1026

Kamus Dewan Edisi Keempat, diakses dari http://prpm.dbp.gov.my/Search.aspx?k=komoditi pada 11 April 2016

Laporan Tahunan. (2014). CIMB Group Holding Berhad, Kuala Lumpur, h. 44.

Muhammad Hasbi Zaenal dan Abdul Hakam. (2014). "Aplikasi dan Analisis Konsep Tawarruq Pada Produk Perbankan: Studi Kasus di CIMB Islamic Bank Bhd. Malaysia”. Al-Amwal. Vol 2. No 2. 
Nazih Hammad. (2005). Al-Uqud al-Murakkeabah fi al-Fiqh al-Islami: Dirasah Ta'siliyyah li al-Manzumat al'Aqdiyyah al-Mustahdathah. Dimashq: Dar al-Qalam

Nisbet. J. dan J. Watt. (1994). Studi Kasus Sebuah Panduan Praktis. Jakarta: PT. Gramedia Widiasarana Indonesia.

Qal'ahji, Muhammad Rawwas et al (pnys). (1416H/1996). Mu'jam Lughat al-Fuqaba': "Arabi-Inklizi-Ifransi: Ma'an Kashshaf Inkliri-'Arabi-Ifransi bi al-Mustalahat al-Waridah fi al-Mu'jam. Beirut: Dar al-Nafa'is. Hlm $131 \& 472$

Stake, RE. (1995). The Art of Case Study Research. Thousand Oaks, CA: Sage Publications.

Ubay Harun. (2006). "Murābahah dalam Perspektif Fiqh dan Hukum Islam”. Jurnal Hukum Islam. Vol 5 . No 3

Wahbah Mustafa al-Zuhayli. (2004). Al-Fiqh al-Islami wa' Adillatuh. Dimashq: Dar al-Fikr. Jil 5. Hlm 3457

Wizarat al-Awqaf wa al-Shu'un al-Islamiyyah. (1423H/2002). Al-Mawsu'ah al-Fiqhiyyah al-Kuwaitiyyah. Kuwait: Wizarat al-Awqaf wa al-Shu'un al-Islamiyyah. Juz 3. Hlm 107

Zuhairi Zakaria. (2014). (Shariah Department,Group Islamic Banking Division, CIMB Bank ) dalam temubual emel dengan pengkaji 12 Disember 2014 